\title{
LOCOMOTION PATTERNS OF STALL WALKING IN THOROUGHBRED HORSES
}

\section{PATRONES DE LOCOMOCIÓN DE PASEO CIRCULAR EN PESEBRERA EN CABALLOS PURASANGRE}

\author{
Lisandro Muñoz Alonzo ${ }^{1 *}$, Ronald Rodríguez Riffo ${ }^{1}$, María Cordero Laurie $^{2}$, Jaime Cruces Leal ${ }^{1}$, y \\ Mario Briones Luengo ${ }^{2}$ \\ ${ }^{1}$ Departamento de Ciencias Clínicas, Facultad de Ciencias Veterinarias, Universidad de Concepción, \\ Victoria 495, Concepción, Chile. \\ 2 Departamento de Ciencia Animal, Facultad de Ciencias Veterinarias, Universidad de Concepción, Av. \\ Vicente Méndez 595, Chillán, Chile. \\ *Corresponding author E-mail: lismunoz@udec.cl
}

\begin{abstract}
There are few studies on locomotion patterns of horses and the amounts of time they spend stall walking. The objective of this study was to describe the locomotion patterns of horses performing stall walking. The time animals spent in this stereotype was also recorded. Ten thoroughbred racehorses residing in the Club Hípico de Concepción and exhibiting stall walking behavior were recorded continuously in their own stalls from 15:00-18:00 over two days in a row. Locomotion patterns (direction and gait) and time spent (loops per hour walking around the stall and duration of each round) were described. Nine of ten horses $(90 \%)$ showed a unique locomotion pattern inside the stall, such as walking or trotting in only one direction around the stall without stopping; walking in only one direction around the stall and stopping at the door; walking in one direction around the stall and stopping at the door and in a corner different from the door; walking in one direction and stopping eventually in four locations of the stall; and walking forming an eight by the wall opposite to the door. Just one of the horses performed two types of patterns. Mean stall walking time was $31.4 \pm 22.3 \mathrm{~min}$ during the observation period. The results indicate that, under similar management conditions, thoroughbred horses performed different locomotion patterns. Besides, the time horses spent performing stall walking ranged between $3.9 \%$ and $41.7 \%$ of the observation time. No increase of stall walking frequency was observed before feeding time.
\end{abstract}

Key words: stereotypic behavior, stall walking, box walking, equines, horses

\section{RESUMEN}

Hay pocos estudios sobre patrones de locomoción y tiempo ocupado en realizar paseo circular en pesebrera en caballos. El objetivo del estudio fue describir los patrones de locomoción de caballos con paseo circular en pesebrera. También fue registrado el tiempo ocupado en paseo circular en pesebrera. Diez caballos purasangre de carrera del Club Hípico de Concepción, con paseo circular en pesebrera fueron filmados en su pesebrera entre las 15:00-18:00 h durante dos días seguidos. Se describieron los patrones de locomoción (dirección y aire) y tiempo ocupado (vueltas por hora y duración de cada vuelta). Nueve de 10 caballos $(\mathbf{9 0} \%)$ realizaron un único patrón de locomoción en la pesebrera: caminar o trotar en una dirección alrededor de la pesebrera sin parar; caminar en una dirección alrededor de la pesebrera y parar en la puerta; caminar en una dirección alrededor de la

Received: 04 June 2019. Accepted: 01 July 2019. 
pesebrera, parando en la puerta y en una esquina diferente a la puerta; caminar en una dirección parando en cuatro lugares de la pesebrera; y caminar en ocho en la pared opuesta a la puerta. Sólo un caballo realizó dos patrones. El tiempo promedio en realizar paseo circular en pesebrera fue 31,4 \pm 22 , 3 min durante el periodo de observación. Nuestros resultados indican que bajo condiciones similares de manejo, los caballos purasangre realizan diferentes patrones de locomoción. Además, el tiempo ocupado en realizar paseo circular en pesebrera varió entre 3,9\% y 41,7\% del tiempo de observación. No se observó aumento en la frecuencia de paseo circular en pesebrera antes de recibir alimento.

Palabras clave: conducta estereotípica, caminar en pesebrera, caminar en corral, caballos, equinos

\section{INTRODUCTION}

Limited research exists regarding locomotion patterns of horses and the amounts of time they spend stall walking. Stall walking (USA), also called box-walking (UK) (McGreevy, 2012), circling, and perimeter walking (McDonnell, 2003) is a locomotor stereotypic behavior characterized by horse walking in a constant path around his stall, alternating directions or forming an eight pattern (Rebdo et al., 1998; McGreevy, 2011). This behavior is associated with stress situations (Sarrafchi and Blokhuis, 2013; Roberts et al., 2017; Williams and Randle, 2017), such as confinement in a stall for many hours (Normando et al., 2011), without direct contact with other horses (Bachmann et al., 2003). However, stall walking is most often seen when a horse is separated from another horse (McGreevy, 2011) or before an event, such as feed or release from the stall, which produces anxiety and frustration (Mills et al., 2005). Stall walking is frequent in thoroughbred horses (McGreevy et al., 1995; Luescher et al., 1998; Pell and McGreevy, 1999; Mills et al., 2002; Waters et al., 2002; Bachmann et al., 2003). A prevalence between $2.02 \%$ and $5.28 \%$ has been reported for this stereotypy in thoroughbred racehorses in Chile (Tadich et al., 2013; Muñoz et al., 2014; Muñoz et al., 2017; Muñoz et al., 2018). Some reports have indicated that predisposition to rhabdomyolysis, and decrease in body weight or sports performance are among the consequences associated with this behavior in thoroughbred horses (Wickens and Houpt, 2015). However, there is only one study that has reported the amount of time a horse spends stall walking, based on an observation period of four hours over one day (Ninomiya et al., 2007).

Stall walking can lead to abnormal horseshoes or hoof wearing (Ninomiya et al., 2007), or pose a risk of muscle damage (asymmetry of back muscles), affecting the horse's sports performance (McGreevy, 2011). Besides, the time a horse stall walks could help predict future risks of dehydration, muscle fatigue and rhabdomyolysis
(Marsden, 2008). Given the limited information available, the objective of this study was to describe locomotion patterns and estimate the amount of time thoroughbred horses spend performing stall walking.

\section{MATERIALS AND METHODS}

The study was conducted in the facilities of the Club Hípico de Concepción, Concepción, Chile. First, horse owners or keepers were asked about the existence of stall walking among their thoroughbred horses. As an observational study performed on a finite population, the horses selected were all those that exhibited stall walking behavior (according to the description by McGreevy, 2011), and met the following inclusion criteria: healthy, without lameness and active in training and/or competition. The selection was made by a veterinarian with vast experience in clinical and equine behavior. The horses studied were seven mares, two stallions and one gelding, between 2 and 5 years old, weighing between 414 and $481 \mathrm{~kg}$. The subjects remained in their own stall ( $3.5 \times 3.5 \mathrm{~m}$ with wood chip horse bedding), with no modification of their daily routine. They were stabled for more than 22 hours per day, with auditory and visual but no physical contact with other horses. Horses were supplied with water ad libitum and feeding based on alfalfa (Medicago sativa) grass hay $(3.4 \pm 0.5 \mathrm{~kg}$ per day) and oat (Avena sativa grains $(9.3 \pm 1.8 \mathrm{~kg}$ per day) and/or sweet pellets $(0.5 \pm 0.1 \mathrm{~kg}$ per day). Their daily routine began with delivery of food at 08:00 $\mathrm{h}$ followed by the removal of stall bandage and blanket, body grooming and then training. All horses had a similar training program, which consisted of one or more of the following activities performed once a day between 09:00 and 12:00 $\mathrm{h}$ : riding at the walk (20 to $30 \mathrm{~min}$ ), lunging in a round pen, galloping with a raider at different intensities (5 to $10 \mathrm{~min}$ ) and walking on lead rope (20 to $30 \mathrm{~min}$ ). Weekly races were performed on a smooth track of sand in a clockwise direction, and at distances of 800 to $2000 \mathrm{~m}$, in which only thoroughbred horses participated. After exercise, 
the horses were groomed outside the stall and body protections were applied. Then, the horses were placed into the stall, and had no direct contact with people until the next day, except during feeding time at 12:30 and 18:00 h.

Each horse's caretaker, trainer, or owner was asked about the horse's name, age, and gender. The locomotor behavior of the horses was continuously recorded using a video camera installed $3.5 \mathrm{~m}$ above ground level on the diagonal corner of the door of each horse's stall. This camera was set up to record continuously from 15:00 to 18:00pm, over two days in a row. The data were recorded using a digital video recorder DVR (Ansjer ${ }^{\mathrm{TM}}$, model 720P, Zhuhai, China), equipped with an internal hard drive. Later, the recorded videos were analyzed by only one observer, previously trained to establish locomotion patterns (direction and gait), number of loops (circular route inside the stall, in which the horse passes again through the starting point) per hour and minutes, duration of each loop (seconds), the total time spent (minutes) in stall walking during the 3-hour observation period and also to determine the existence of an increase of stall walking frequency at any time and, particularly, before the feeding routine.

The ethogram used for the study is shown in Table 1.

Descriptive analysis was used to establish the means and standard deviations of the time spent by horses in performing stall walking (total length of time for which all occurrences of the stall walking lasted over three hours of observation). To establish if at any time the frequency of stall walking (number of bouts per time unit) was modified, the observation time was divided into 6 periods of $30 \mathrm{~min}$ each. The number of episodes of stall walking was compared between periods using the Wilcoxon test.

\section{RESULTS AND DISCUSSION}

This study shows graphically different patterns of locomotion and allows estimating the daily time range used by stabled horses in performing stall walking.

Nine of ten $(90 \%)$ horses followed a unique locomotion pattern inside the stall (Fig. 1), such as walking or trotting in only one direction around the stall without stopping $(\mathrm{n}=2)$; walking in only one direction around the stall and stopping at the door $(n=3)$; walking in one direction around the stall and stopping at the door and in a corner different from the door $(\mathrm{n}=2)$; walking in one direction and stopping eventually in four locations of the box $(n=1)$; and walking forming an eight by the wall opposite to the door $(n=1)$. In addition, one horse performed two types of patterns, alternating a full loop around the stall, with an eight figure in $50 \%$ of the perimeter ( $\mathrm{n}=$ 1). The different locomotion patterns observed in the horses with stall walking allow us to expand the already existing descriptions, because most definitions indicate that horses perform a circular path inside the stall (Rebdo et al., 1998; Mills, 2005; Marsden, 2008; Normando et al., 2011; McGreevy, 2012; Wickens and Houpt, 2015) in the same direction, alternating directions, or in the form of an eight figure (Rebdo et al., 1998; Normando et al., 2011). Additionally, it has been reported that horses stop to look out of the door or window or to smell the ground (Marsden, 2008). No previous report has described (graphically) the movement patterns of stall walking in horses in detail.

The fact that two horses were observed trotting inside the stall can be considered as a high-risk behavior since it could cause excessive sweating and fatigue (McGreevy, 2011).

The individual and mean time spent by the horses stall walking was very variable among the ten horses (Table 2). The horses performed from 27 to 303 loops around the stall per hour of observation (0.5 - 6 loops per minute). Each loop around the stall lasted 4 to $12 \mathrm{~s}$ depending on the locomotion pattern and gait, with a range of stall walking from $3.9 \%$ to $41.7 \%$ of the observation time. Differences in time spent in each loop vary according to the gait used by the horse (walk or trot). Besides, they spent the rest of the time

Table 1. Ethogram used in the study.

Tabla 1. Etograma usado en el estudio.

\begin{tabular}{ll}
\hline \multicolumn{1}{c}{ Behavior } & \multicolumn{1}{c}{ Description } \\
\hline Stall walking & $\begin{array}{l}\text { Locomotor stereotypic behavior characterized by a continuous locomotion inside the } \\
\text { stall, alternating directions or forming an eight pattern (adapted from McGreevy, 2011). }\end{array}$ \\
Walk & $\begin{array}{l}\text { Movement forward in the slowest (four beat) of the gait in which the feet move } \\
\text { individually and sequentially in diagonals as follows: right fore, left hind, left fore, right } \\
\text { hind (adapted from McDonnell, 2003; McGreevy, 2012). } \\
\text { Trot }\end{array}$ \\
& $\begin{array}{l}\text { Movement forward in a two-beat gait in which diagonally paired feet touch and lift } \\
\text { simultaneously (McDonnell, 2003). }\end{array}$ \\
\hline
\end{tabular}




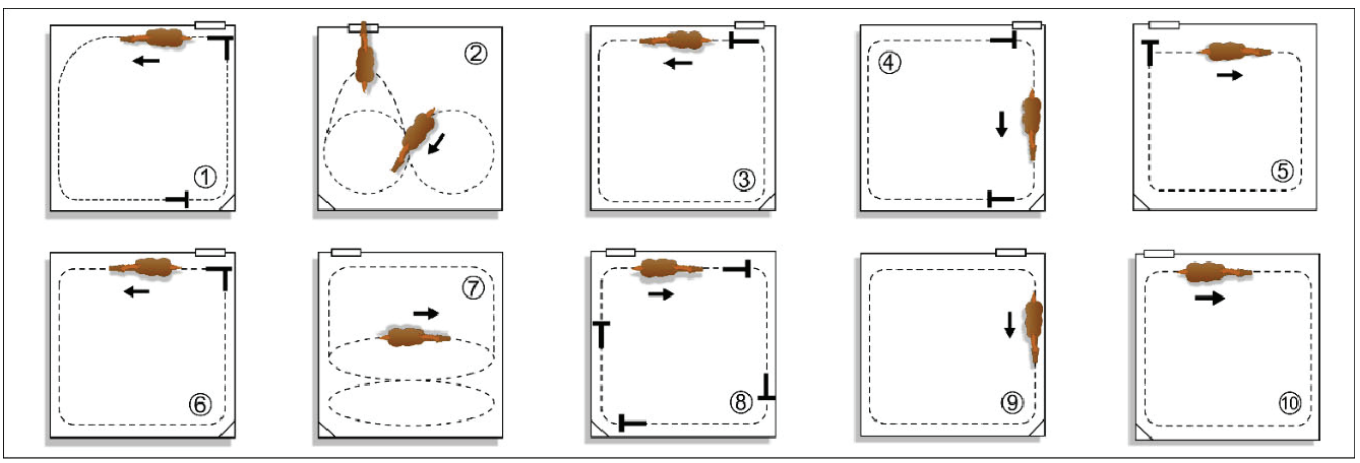

$\mathrm{T}$ : indicate pause.

Fig. 1. Patterns of stall walking of each of the horses in the study $(n=10)$.

Fig. 1. Patrones de paseo circular en pesebrera de cada caballo del estudio $(n=10)$.

Table 2. Individual and mean time ( \pm standard deviation) spent during three daily hours of observation in stabled thoroughbred horses with stall walking during two days $(n=10)$.

Tabla 2. Tiempo individual y promedio ( \pm desviación estándar) ocupado durante tres horas diarias de observación en caballos purasangre estabulados con paseo de circular en pesebrera durante dos días $(\mathrm{n}=10)$.

\begin{tabular}{crrrrrrrrrrr}
\hline \multicolumn{10}{c}{ Individual time spent (min) by horses } \\
\hline Day & 1 & 2 & 3 & 4 & 5 & 6 & 7 & 8 & 9 & 10 & Mean \pm SD \\
1 & 18 & 80 & 22 & 12 & 62 & 25 & 37 & 18 & 24 & 8 & $30.6 \pm 23.1$ \\
2 & 12 & 70 & 23 & 20 & 68 & 23 & 43 & 21 & 34 & 7 & $32.1 \pm 21.9$ \\
Mean & 15 & 75 & 22.5 & 16 & 65 & 24 & 40 & 19.5 & 29 & 7.5 & $31.4 \pm 22.3$ \\
\hline
\end{tabular}

SD: standard deviation.

eating, looking through the window or resting in a standing position; four of them recorded sternal recumbence, while two exhibited lateral recumbence.

There is only one previous report on the amount of time spent by horses walking in the stall. This study was based on the observation of one horse for four hours over one day, in which stall walking reached $35.3 \%$ of the time (Ninomiya et al., 2007). This result is within the range reported in our study. Therefore, the present study provides support for the time range spent in stall walking, and confirms that horses can stall walk for many hours at a rate of several stall loops per minute as stated by Houpt and McDonnell (1993) and Ninomiya et al. (2007). Nevertheless, stall walking time did not exceed the time horses spent daily walking the pasture. In this sense, it has been indicated that this amount of time may reach $69 \%$ in $24 \mathrm{~h}$ (Duncan, 1985; Henderson, 2007), 10000 steps/day (Robert et al., 2017) or at least $16 \mathrm{~km} /$ day in basic maintenance activities such as grazing, walking to drink or towards the shade (McDonnell, 2014). On this regard, a study conducted with 389 thoroughbred racehorses did not show significant statistical differences in terms of frequency of stall walking behavior in groups with higher or lower sports performance (Muñoz et al., 2018). Thus, it is considered that thoroughbred horses shouldn't have an effect of stall walking on their racing performance (Muñoz et al., 2018). Therefore, this behavior can only be a problem in horses that trot in their stalls, because of the great loss of water and electrolytes, and the risk of developing rhabdomyolysis (Houpt and McDonnell, 1993; McCutcheon and Geor, 1996; Harris and Rivero, 2017). In addition, when the nutritional requirements associated with stall walking are not covered, they can be manifested in weight loss (Houpt and McDonnell, 1993; Mills et al., 2002; Wickens and Houpt, 2015). However, it is a fact that stall walking is a sign of inadequate well-being, or past or present states of chronic stress (Kiley-Worthington, 1987; Marsden, 2008). It is also an indicator of a motivation increase to perform a specific behavior that stimulates appetitive behavior, which generates frustration and presence of particular stereotypies due to environmental restraints (McBride and Hemmings, 2009). 
No increase in the frequency of stall walking was observed $(\mathrm{P}>0.05)$ before the afternoon feeding time or at any other time of the observation period. The fact that the frequency of occurrence did not increase before the feeding was an unexpected result. It has been suggested that the stereotypy would be a pre-feeding behavior (Hockenhull and Creighton, 2012), triggered by a conditioned stimuli associated with food arrival (McBride and Hemmings, 2009). However, Hothersall and Nicol (2013) have indicated that there is little evidence of association between stall walking and feeding.

The main limitation of this study was the duration of the observation time since observations were not conducted for a whole 24-hour period and/or more days. However, it provides information that allows estimating the time horses spend stall walking before feeding time.

\section{CONCLUSIONS}

The results indicate that under similar management conditions, thoroughbred horses performed different locomotion patterns, with stall walking ranging between $3.9 \%$ and $41.7 \%$ of the observation time.

\section{LITERATURE CITED}

Bachmann, I., L. Audigé, and M. Stauffacher. 2003. Risk factors associated with behavioural disorders of crib-biting, weaving and boxwalking in Swiss horses. Equine Vet. J. 35:158-163.

Duncan, P. 1985. Time-budgets of Camargue horses. III Environmental influences. Behaviour 92:188-208.

Harris, P.A., and J.L.L. Rivero. 2017. Nutritional considerations for equine rhabdomyolysis syndrome. Equine Vet. Educ. 29:459-465.

Henderson, A.J.Z. 2007. Don't fence me in: managing psychological well-being for elite performance horses. J. Appl. Anim. Welf. Sci. 10:3099-329.

Hockenhull, J., and J. Creighton. 2012. Are breed and sex associated with the likelihood of stabled UK leisure horses displaying stereotypic behaviour? p. 122. In Proceedings of the 46th Congress of the International Society for Applied Ethology, Vienna, Austria.

Hothersall B., and C.J. Nicol. 2013. Effects of diet on behavior - normal and abnormal. p. 443454. In R.J. Geor, P.A. Harris, and M. Coenen (eds.). Equine applied and clinical nutrition. health, welfare and performance. Saunders Elsevier, Edinburgh, UK.
Houpt, K.A., and S.M. McDonnell. 1993. Equine stereotypies. Compend. Continuing Educ. 15:1265-1271.

Kiley-Worthington, M. 1987. The behaviour of horse. In relation to management and training. J.A. Allen \& Company Limited, London, UK.

Luescher, U.A., D.B. McKeown, and H. Dean. 1998. A cross-sectional study on compulsive behavior (stable vices) in horses. Equine Vet. J. Suppl. 27:14-18.

Marsden, M.D. 2008. Stereotypic and other behaviour problems. p. 373-402. In M. Furr, and S. Reed (eds.). Equine neurology. Blackwell, Ames, USA.

McBride, S., and A. Hemmings. 2009. A neurologic perspective of equine stereotypy. J. Equine Vet. Sci. 29:10-16.

McCutcheon, L.J., and R.J. Geor. 1996. Sweat fluid and ion losses in horses during training and competition in cool vs. hot ambient conditions: implications for ion supplementation. Equine Vet. J. Suppl. 22:54-62.

McDonnell, S. 2003. A practical field guide to horse behavior. The equid ethogram. Eclipse Press, Hong Kong, China.

McDonnell, S.M. 2014. Herd dynamics. p. 261. In Proceedings of the British Equine Veterinary Association Congress, Birmingham, UK.

McGreevy, P. 2011. Stereotypic behaviour. p. 2771-2775. In A.O. McKinnon, E.L. Squires, W.E .Vaala, and D.D. Varner (eds.). Equine reproduction. $2^{\text {nd }}$ ed. Blackwell, Ames, USA.

McGreevy, P. 2012. Equine behavior. A guide for veterinarians and equine scientists. $2^{\text {nd }} \mathrm{ed}$. Saunders, Philadelphia, USA

McGreevy, P.D., P.J. Cripps, N.P. French, L.E. Green, and C.J. Nicol. 1995. Management factors associated with stereotypic and redirected behaviour in the thoroughbred horse. Equine Vet. J. 27:86-91.

Mills, D.S. 2005. Repetitive movement problems in the horse. p. 212-227. In D. Mills, and S. McDonnell (eds.). The domestic horse. The evolution, development and management of its behaviour. Cambridge University Press, Cambridge, UK.

Mills, D.S, R.D. Alston, V. Rogers, and N.T. Longford. 2002. Factors associated with the prevalence of stereotypic behaviour amongst thoroughbred horses passing through auctioneer sales. Appl. Anim. Behav. Sci. 78:115-124.

Mills, D.S., K.D. Taylor, and J. Cooper. 2005. Weaving, headshaking, cribbing, and other stereotypies. In Proceedings 51st of the Annual Convention of the American Association of Equine Practitioners. Seattle, USA. 
Muñoz, L., F. Ainardi, C. Rehhof, J. Cruces, R. Ortiz, and M. Briones. 2014. Prevalence of stereotypies in thoroughbred race horses at Club Hípico Concepción, Chile. Rev. MVZ Córdoba 19:4259-4268.

Muñoz, L., J. Cruces, and M. Briones. 2017. Prevalencia de estereotipias clásicas en caballos fina sangre de carrera del Hipódromo Chile, Chile. Rev. Med. Vet. (Colombia) 33:51-57.

Muñoz, L., C. León, J. Cruces, R. Ortiz, and M. Briones. 2018. Locomotor stereotypies and racing performance in thoroughbred horses. J. Vet. Behav. 25:24-27.

Ninomiya, S., S. Sato, and K. Sugawara. 2007. Weaving in stabled horses and its relationship to other behavioural traits. Appl. Anim. Behav. Sci. 106:134-143.

Normando, S., L. Meers, W.E. Samuels, M. Faustino, and F.O. Ödberg. 2011. Variables affecting the prevalence of behavioural problems in horses. Can riding style and other management factors be significant? Appl. Anim. Behav. Sci. 133:186-198.

Pell, S.M., and P.D. McGreevy. 1999. Prevalence of stereotypic and other problem behaviours in thoroughbred horses. Aust. Vet. J. 77:678679.

Redbo, I., P. Redbo-Torstensson, F.O. Ödberg, A. Hedendahl, and J. Holm. 1998. Factors affecting behavioural disturbances in race horses. Anim. Sci. 66:475-481.
Roberts, K., A.J. Hemmings, S.D. McBride, and M.O. Parker. 2017. Causal factors of oral versus locomotor stereotypy in the horse. J. Vet. Behav. 20:37-43.

Sarrafchi, A., and H.J. Blokhuis. 2013. Equine stereotypic behaviours: causation, occurrence, and prevention. J. Vet. Behav. 8:386-394.

Tadich, T., C. Weber, and C.J. Nicol. 2013. Prevalence and factors associated with abnormal behaviors in Chilean racehorses: a direct observational study. J. Equine Vet. Sci. 33:95-100.

Waters, A.J., C.J. Nicol, and N.P. French. 2002. Factors influencing the development of stereotypic and redirected behaviours in young horses: findings of a four year prospective epidemiological study. Equine Vet. J. 34:572-579.

Wickens, C.L., and K.A. Houpt. 2015. Stereotypic and behavior disorders. p. 472-483.In M. Furr, and S. Reed (eds.). Equine neurology. Blackwell, Ames, USA.

Williams, J., and H. Randle. 2017. Is the expression of stereotypic behaviour a performancelimiting factor in animals? J. Vet. Behav. 20:110. 